\title{
Histomorphological Profile of Liver and Kidney Tissues of Albino Wistar Rats Following Exposure to Cadmium-Induced Damage and Ascorbic Acid Supplementation
}

\author{
Uche C. Okwuonu', Dayo R. Omotoso', Emmanuel O. Bienonwu', Osahenrhumwen Adagbonyin'², Joseph Dappa ${ }^{3}$ \\ ${ }^{1} \mathrm{PhD}$, Department of Anatomy, College of Health Sciences, Igbinedion University, Okada, Edo State, Nigeria, ${ }^{2} \mathrm{MBBS}$, Department of Anatomy, College of \\ Health Sciences, Igbinedion University, Okada, Edo State, Nigeria, ${ }^{3}$ BSc, Department of Anatomy, College of Health Sciences, Igbinedion University, \\ Okada, Edo State, Nigeria.
}

\section{Abstract}

Introduction: Cadmium is a common heavy metal toxicant that can cause diverse tissue toxicities and pathologies. Conversely, ascorbic acid is a natural anti-oxidant that can ameliorate cytotoxic effects of tissue toxicants. In this study, the objective was to assess the histomorphological profile of liver and kidney tissues of albino Wistar rats after exposure to cadmium-induced damage and ascorbic acid supplementation. Subjects and Methods: 24 animals were divided into four groups (1-4) comprising of six animals each (n=6). Normal control group 1 was given distilled water, test control group 2 given $5 \mathrm{mg} / \mathrm{kg}$ Cadmium chloride and test groups 3 and 4 given $5 \mathrm{mg} / \mathrm{kg}$ Cadmium chloride $+100 \mathrm{mg} / \mathrm{kg}$ ascorbic acid and $5 \mathrm{mg} / \mathrm{kg}+200 \mathrm{mg} / \mathrm{kg}$ ascorbic acid respectively. The route of the $21 \mathrm{days}$ administration was oral. Thereafter, the liver and kidney of experimental animals were harvested, weighed and processed. Results: Only the test control group 2 showed significant $(\mathrm{p}<0.05)$ reduction in mean organ weight compared to normal control group 1 . Similarly, only the test control group 2 animals showed significant alterations in the liver and kidney histomorphological profile compared to normal control group 1. Conclusion: The ascorbic acid exhibited prominent ameliorative effect against damaging effect of cadmium exposure leading to relative reparation of liver and kidney histomorphology in albino Wistar rats.

Keywords: Liver histomorphology, Kidney histomorphology, Cadmium, Ascorbic acid, Wistar rats.

Corresponding Author: Dr. Dayo R. Omotoso, Department of Anatomy, College of Health Sciences, Igbinedion University, Okada, Edo State, Nigeria.

Received: December 2019

Accepted: January 2020

\section{Introduction}

Environmental toxicants have become a major source of health hazards to humans thereby impacting negatively on the health and overall well-being of exposed individuals. Among these environmental toxicants, heavy metals stand out as major cause various tissue pathologies and threat to health status of an individual. ${ }^{[1]}$ During exposure to tissue toxicants including heavy metals, the liver and kidney tissues are among the most susceptible bodily tissues to their toxic effects. ${ }^{[2,3]}$ One of such heavy metal is cadmium whose exposure has been linked with various tissue toxicities including nervous, respiratory, reproductive, cardiovascular, hepatic and renal tissues. ${ }^{[4-6]}$

Cadmium is a non-biodegradable heavy metal which possesses a relatively long half-life and readily accumulates in bodily tissues wherein it produces tissue toxicities leading to tissue dysfunction. ${ }^{[7-10]}$ The cadmium exposure and accumulation in these tissues cause significant reduction of activities of certain anti-oxidant enzymes and induced membrane lipid peroxidation and oxidative damage. ${ }^{[1-13]}$ The oxidative tissue damage that follows cadmium exposure have been described to results from generation of reactive oxygen species such as hydrogen peroxide and thiobarbituric acid reactive substances that act to impair the anti-oxidant defence system. ${ }^{[14-16]}$

On the other hand, anti-oxidants, such as ascorbic acid, act to ameliorate the cytotoxic effects of tissue toxicants. It functions as electron-carrier similar to other free radical scavengers such as glutathione, $\beta$-carotene and Vitamin E. ${ }^{[17,18]}$ This anti-toxic property of ascorbic acid invariably translates into cytoprotection of histomorphology of biological tissues particularly hepatic and renal tissue.

Therefore, the objective of this study was to assess the histomorphological profile of liver and kidney tissues of albino Wistar rats after exposure to cadmium-induced damage and ascorbic acid supplementation.

\section{Subjects and Methods}

\section{Experimental animals}

This study involved twenty four (24) albino Wistar rats with body weight ranging between $150 \mathrm{~g}-185 \mathrm{~g}$. The experimental animals were procured from and housed at the Central Animal House Facility of Igbinedion University, 
Okada, Edo State, Nigeria where the study was subsequently conducted. During the study period, the animals were kept in cages under hygienic conditions, at $24 \pm 20 \mathrm{C}$ room temperature, $57 \pm 2 \%$ relative humidity and $12-12$ hour lightdarkness cycle. The experimental animals were allowed regular access to animal feed and drinking water ad libitum.

\section{Experimental design}

The experimental animals were randomly grouped into four groups $(1-4)$ comprising six (6) animals per group (n=6).

\begin{tabular}{|l|l|l|l|l|}
\hline Groups & Description & Number of animals $(\mathbf{n})$ & Exposure & Dosage/Body weight \\
\hline 1 & Normal control & 6 & No induction, No treatment & $5 \mathrm{~mL} / \mathrm{kg}$ distilled water \\
\hline 2 & Test Control & 6 & Induced + No treatment & $5 \mathrm{mg} / \mathrm{kg}$ Cadmium chloride in drinking water \\
\hline 3 & Test group & 6 & Induced + treated & $\begin{array}{l}5 \mathrm{mg} / \mathrm{kg} \text { Cadmium chloride in drinking water }+100 \mathrm{mg} / \mathrm{kg} \\
\text { ascorbic acid }\end{array}$ \\
\hline 4 & Test group & 6 & Induced + treated & $\begin{array}{l}5 \mathrm{mg} / \mathrm{kg} \text { Cadmium chloride in drinking water }+200 \mathrm{mg} / \mathrm{kg} \\
\text { ascorbic acid }\end{array}$ \\
\hline
\end{tabular}

All administrations were conducted orally using an orogastric gavage coupled to a calibrated hypodermic syringe, everyday for 21 days.

\section{Tissue processing, sectioning and staining}

After the study period, experimental animals were sacrificed and their liver and kidney tissues harvested, weighed and processed for histological staining. During tissue processing, 10\% Neutral Buffered Formalin was used to fixed the tissue, alcohol was used as dehydrating agent and xylene was used as clearing agent. Processed liver and kidney tissues of experimental animals were embedded in molten paraffin wax and allowed to solidify to form tissue blocks. The liver and kidney tissue blocks were sectioned at $5 \mu$ thickness and stained by Haematoxylin and Eosin (H \& E) technique for subsequent histomorphological study.

\section{Histopathological study}

Stained liver and kidney tissue sections were viewed under microscope and photomicrograph of each section generated for further analysis. The histomorphological profile of the liver and kidney tissues of experimental animals was assessed and observable histopathological changes were quantified using the image-J software (National Institute of Health, Bethesda, MA, USA). All data generated during the study were recorded and statistically analyzed.

\section{Statistical analysis}

The data obtained during this study were presented as mean \pm standard error of mean (SEM) following their analysis using the IBM-SPSS (version 20, IBM Corp., NY, USA). Comparison of statistical results was done using t-test and analysis of variance (ANOVA) with the level of statistical significance set at $\mathrm{p}<0.05$.

\section{Results}

\section{Assessment of weight of experimental tissues}

The mean weight values of liver tissue of experimental animals in normal control group 1, test control group 2 and treated groups 3 and 4 were given in [Figure 1] while the mean weight values of kidney tissue of experimental animals in corresponding groups were given in [Figure 2]. From these findings, the mean weight values of liver and kidney tissues of experimental animals showed significant ( $\mathrm{p}<$ 0.05) decrease in test control group 2 but an insignificant decrease among the test groups 3 and 4 when compared to the normal groups 1.

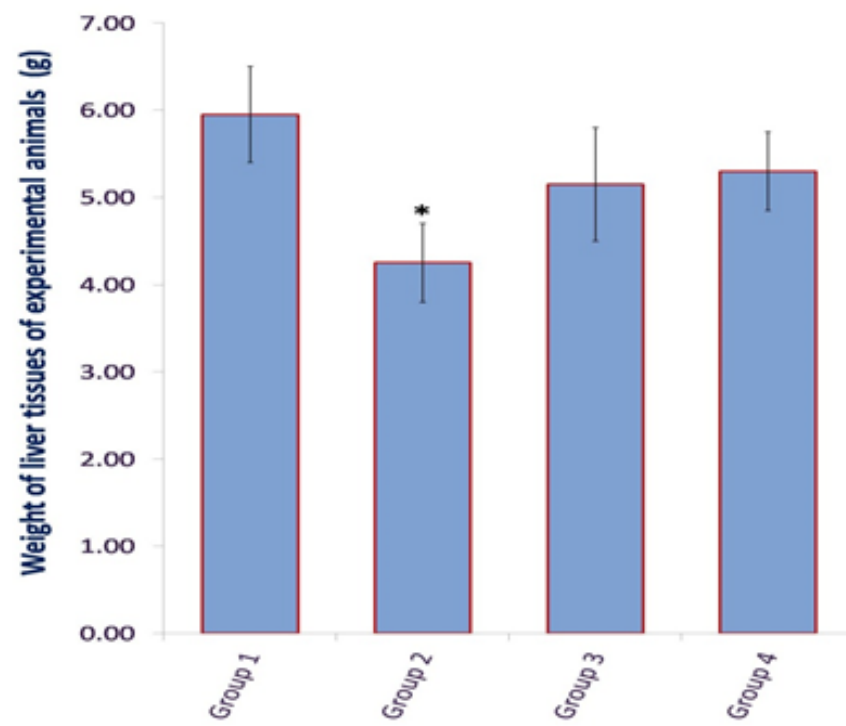

Figure 1: Mean weight values of liver tissues of experimental animals in normal control group 1, test control group 2 and treated groups 3 and 4 (* indicates significant difference at $\mathbf{p}<$ 0.05 in comparison to Groups 1).

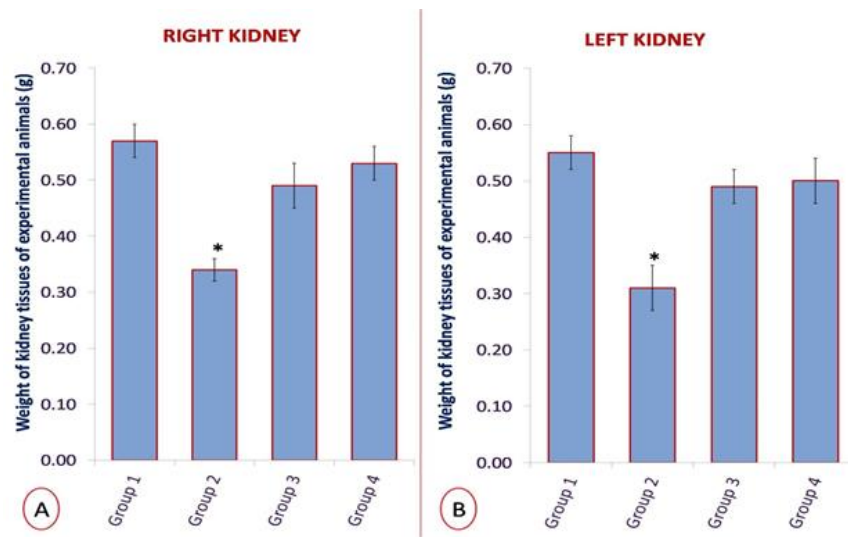

Figure 2: Mean weight values of Right $(A)$ and Left (B) kidney tissues of experimental animals in normal control group 1, test control group 2 and treated groups 3 and 4 (* indicates significant difference at $p<0.05$ in comparison to Groups 1 ).

\section{Histopathological results}

The microscopic examination of liver and kidney tissue of experimental animals showed the histomorphological profile of normal control group 1, test control group 2 and treated groups 3 and 4 animals [Figures 3 \& 4]. The quantified histomorphological alterations in liver tissues included necrosis, inflammation and steatosis [Figure 5] while that of 
the kidney tissues included necrosis, inflammation and glomerular congestion [Figure 6].

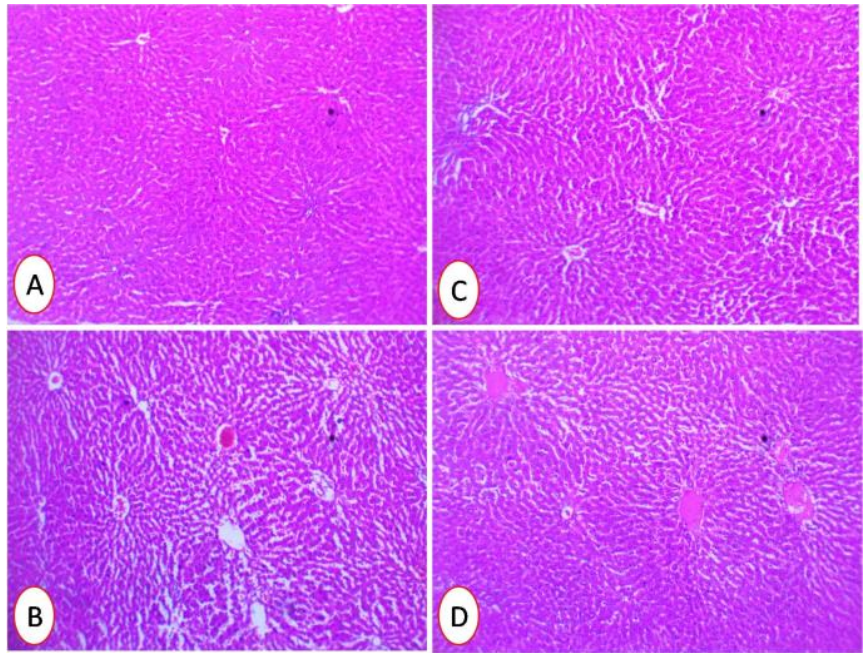

Figure 3: Micrograph showing liver tissue histomorphology of experimental animals in normal control group 1 (A), test control group 2 (B) and treated groups 3 (C) and 4 (D).

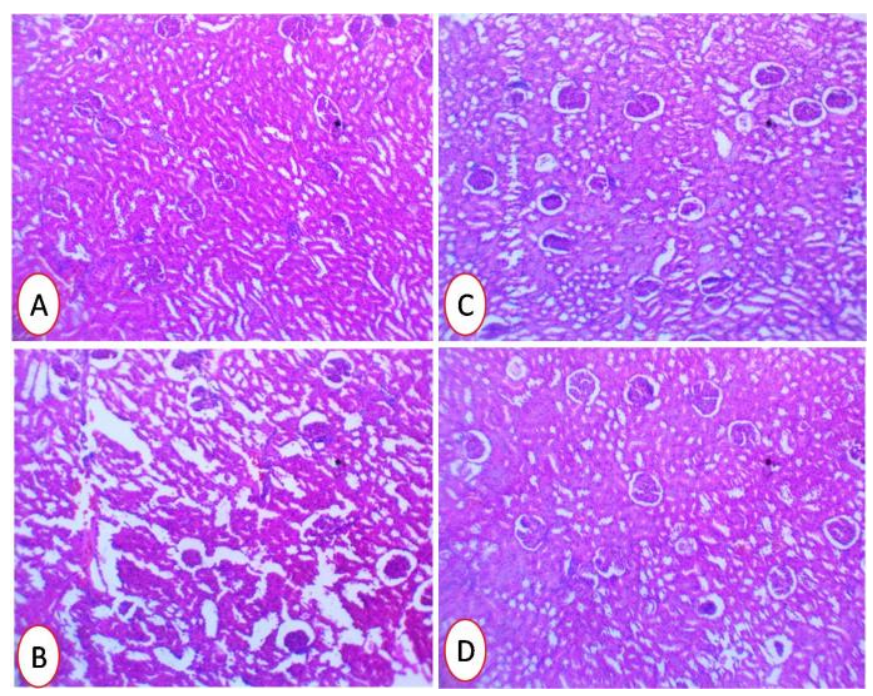

Figure 4: Micrograph showing kidney tissue histomorphology of experimental animals in normal control group 1 (A), test control group 2 (B) and treated groups 3 (C) and 4 (D).

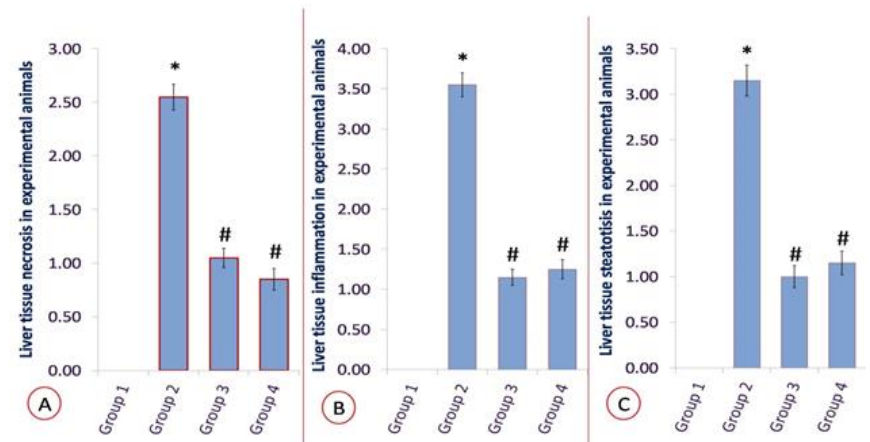

Figure 5: Evaluation of liver tissue necrosis (A), inflammation (B) and steatosis $(C)$ in normal control group 1 , test control group 2 and treated groups 3 and 4 experimental animals (* and \# indicate significant difference at $\mathrm{p}<0.05$ in comparison to Groups 1 and 2 respectively).

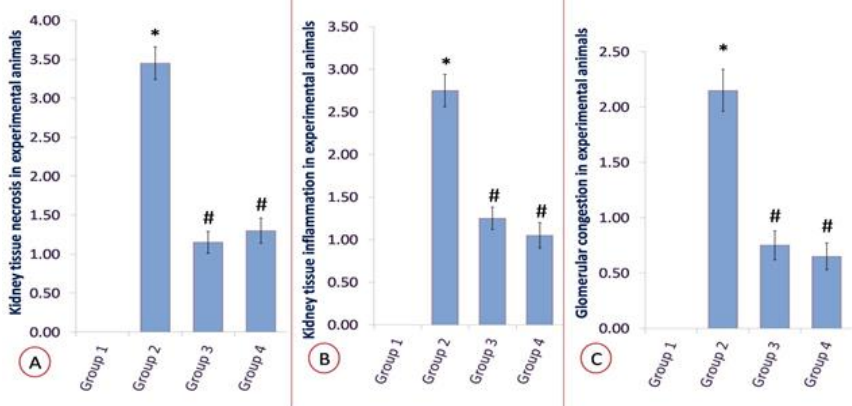

Figure 6: Evaluation of kidney tissue necrosis (A), inflammation (B) and glomerular congestion (C) in normal control group 1, test control group 2 and treated groups 3 and 4 experimental animals (* and \# indicate significant difference at $\mathbf{p}<0.05$ in comparison to Groups 1 and 2 respectively).

\section{Discussion}

The potency of cadmium as tissue toxicant affecting wide range of bodily tissues including the liver and kidney has been widely reported. ${ }^{[19-21]}$ Such cadmium-induced toxicity can adversely impact the weight of distinctly exposed tissues and the overall body weight. ${ }^{[22,23]}$ According to the results of this study [Figures 1\&2], test control group 2 animals, exposed to cadmium only, showed significant reduction of mean weight of liver and kidney tissues relative to normal control group 1 animals. In test groups 3 and 4 animals, due to ascorbic acid supplementation, the mean weight of liver and kidney tissues showed marginal, non-significant reduction compared to the normal control group 1 .

Furthermore, the cadmium-induced tissue toxicity has been indicated by altered haematological and biochemical parameters. $^{[24,25]}$ Asides the significant alterations in different haematological and biochemical indicators of cadmium-induced hepato-renal tissue toxicity, cadmium exposure may also leads to pathological changes in the histomorphology of exposed tissue. However, the ascorbic acid has been described as a potent antioxidant that can ameliorate adverse or deleterious effects of tissue toxicant such as cadmium exposure. Studies by Rehka et al. ${ }^{[26]}$ and Sharaf et al. ${ }^{[27]}$ reported that protective activity of ascorbic acid against toxic effects of heavy metals such as cadmium is characterized by modulation of heamatological and biochemical markers of tissue toxicity and resultant histomorphological reparation of the exposed tissue.

According to the findings of this study [Figures 3\&5], cadmium exposure resulted in significant inflammatory response in the hepatic tissue of experimental animals as well as other histomorphological changes such as necrosis and steatosis. Also, the exposure resulted in significant inflammatory response in kidney tissue of experimental animals and other histomorphological changes such as necrosis and glomerular congestion [Figures 4\&6]. Conversely, the treatment of experimental animals with variable dosage of ascorbic acid showed prominent reparation of histomorphology of exposed liver and kidney tissues.

During tissue toxicity, including cadmium-induced toxicity, free radicals generated by oxidative damage to membrane lipids and lipoproteins can cause cellular damage and 
apoptosis. ${ }^{[20,28]}$ This can further culminate into pathological changes in the histomorphology of exposed tissues. However, ascorbic acid is a natural antioxidant that can potently cause inhibition or scavenging of free radicals thereby ameliorating the damaging effects of tissue toxicants. ${ }^{[29]}$ It is an essential vitamin and anti-toxin which potently functions to reduces the deleterious effects of toxic agents in biological tissues. Each molecule of ascorbic acid contains two hydrogen atoms that bear two high-energy electrons which can be readily donated to reduce oxidation by free radicals thereby neutralizing or ameliorating the deleterious effects of tissue toxins. ${ }^{[18,30,31]}$

These previous studies highlighted the anti-oxidant and cytoprotective activity of ascorbic acid which corroborated the findings of this study on ameliorative activity of ascorbic acid against damaging effect of cadmium exposure on histomorphology of liver and kidney tissues of experimental animals.

\section{Conclusion}

The findings of this study affirmed the potency of cadmium exposure in pathological alteration of histomorphology of bodily tissues including the liver and kidney as well as the anti-toxicant activity of ascorbic acid leading to amelioration of the damaging effects of cadmium exposure on the hepatorenal histomorphological profile.

\section{Acknowledgement}

The authors wish to appreciate the support of the Department of Anatomy, Igbinedion University, Okada, Edo State, Nigeria towards the successful completion of this study.

\section{References}

1. Akomolafe RO, Imafidon CE, Olukiran OS, Oladele AA, Ajayi AO. Livolin Forte ameliorate cadmium-induced kidney in Wistar rats. Ser J Exp Clin Res 2016; 17(2): 107-116. doi: 10.1515/SJECR-2016-0033

2. Yang $\mathrm{H}$, Shu Y. Cadmium transporters in the kidney and cadmium-induced nephrotoxicity. Int J Mol Sci 2015; 16: 14841494. doi:10.3390/ijms 16011484

3. Omotoso DR, Eze GI. Antiproliferative potential of methanolic extracts of Ageratum conyzoides linnaeus via downregulation of ki-67 and upregulation of p53 protein expression in hepatic tissue of rats. Niger J Exp Clin Biosci 2019; 7:35-40 doi: 10.4103/njecp.njecp_21_19

4. Cinar M. Cadmium and effects at biological system. Veterinarium. 2003; 14: 79-84

5. Abd-El-Baset M, Abd El-reheem A. The roles of honeybee solution on the physiological parameters of rats exposed to cadmium chloride. Aust J Basic \& Appl Sci 2008; 2: 1438-1453.

6. El-Sokkary GH, Awadalla EA. The protective role of vitamin C against cerebral and pulmonary damage induced by cadmium chloride in male adult albino rat. Open Neuroendocrinol. J 2011; 4: $1-8$.

7. Friberg L, Elinder CG, Kjellstrom T, Nordberg GF. Cadmium and Health: A Toxicological and Epidemiological Appraisal. Boca Raton, FL: CRC Press. 1986.

8. Klaassen CD, Liu J, Choudhuri S. Metallothionein: An intracellular protein to protect against cadmium toxicity. Ann Rev Pharmacol Toxicol 1999; 39: 267-294.

9. Asagba SO, Eriyamremu GE, Adaikpoh MA, Ezeoma A. Levels of lipid peroxidation, superoxide dismutase, and $\mathrm{Na}+\mathrm{K}+$ ATPase in some tissues of rats exposed to a Nigerian-like diet and cadmium. Biol Trace Elem Res 2004; 100:75-86.

10. Ognjanović BI, Marković SD, Ethordević NZ, Trbojević IS, Stajn AS, Saicić ZS. Cadmium-induced lipid peroxidation and changes in antioxidant defense system in the rat testes: protective role of coenzyme Q (10) and vitamin E. Reprod Toxicol 2010; 29: 191197.

11. Reyes JL, Lamas M, Martin D, del Carmen Namorado M, Islas S, Luna J. The renal segmental distribution of claudins changes with development. Kidney Int 2002; 62: 476-487.

12. El-Sharaky AS, Newairy AA, Badreldeen MM, Eweda SM, Sheweita SA. Protective role of selenium against renal toxicity induced by cadmium in rats. Toxicology 2007; 235: 185-193.

13. Liu J, Qian SY, Guo Q, Jiang J, Waalkes MP, Mason RP, Kadiiska MB. Cadmium generates reactive oxy- gen- and carbon-centered radical species in rats: insights from in vivo spin-trapping studies. Free Radic Biol Med 2008; 45:475-481.

14. Jahangir T, Khan TH, Prasad L, Sultana S. Alleviation of free radical mediated oxidative and genotoxic eff ects of cadmium by farnesol in Swiss albino mice. Redox Rep 2005; 10: 303-310.

15. Swarup D, Naresh R, Varshney VP, Balagangatharathilagar M, Kumar P, Nandi D. Changes in plasma hormones profi le and liver function in cows naturally exposed to lead and cadmium around different industrial areas. Res Vet Sci 2007; 82: 16-21.

16. Ojo OA, Ajiboye BO, Oyinloye BE, Ojo AB, Olarewaju OI. Protective effect of Irvingia gabonensis stem bark extract on cadmium-induced nephrotoxicity in rats. Interdis Toxicol 2014; 208-214.

17. Sies H, Stahl W. Vitamins E and C, beta-carotene and other carotenoids as antioxidants. Am J Clin Nutr 1995; 62: 1315S$1321 \mathrm{~S}$.

18. Oguntibeju OO. The biochemical, physiological and therapeutic roles of ascorbic acid. Afr J Biotechnol 2008; 7(25): 4700-4705.

19. El-Refaiy AI, Eissa FI. Protective effects of ascorbic acid and zinc against cadmium-induced histopathological, histochemical and cytogenetic changes in rats. Comunicata Scientiae 2012; 3(3): 162180.

20. Mohammed ET, Hashem KS, Abdel Rheim MR. Biochemical study on the impact of Nigella sativa and virgin olive oils on cadmium-induced nephrotoxicity and neurotoxicity in rats. J Invest Biochem 2014; 3(2): 70-77.

21. Safhi MM, Khuwaja G, Alam MF, Hussain S, Siddiqui MH, Islam F, Islam F. Cadmium-induced nephrotoxicity via oxidative stress in male Wistar rats and capsaicin protects its toxicity. Bull Environ Pharm Life Sci 2016; 5(3): 5-11.

22. El-Sayed A, Salem SM, El-Garhy AA, Rahman ZA, Kandil AM. Protective effect of zinc against cadmium toxicity in pregnant rats and their foetuses at morphological, physiological and molecular level. Afr J Biotechnol 2013; 12(16): 2110-2119.

23. Vijaya P, Sharma S. Ameliorative efficacy of garlic and tomato extract against cadmium induced renal toxicity in albino mice. J Pharmaceut Chem Biol Sci 2018; 6(2): 13-22.

24. Metwally MMM, Hashem MA. Protective role of garlic against cadmium toxicity in rats: Clinicopathological and histopathological studies. Egypt J Comp Path Clinic Path 2009; 22(3): 114-140.

25. Andjelkovic M, Djordjevic AB, Antonijevic E, Antonijevic B, Stanic M, Kotur-Stevuljevic J, Spasojevic-Kalimanovska V, Jovanovic M, Boricic N, Wallace D, Bulat Z. Toxic effect of acute cadmium and lead exposure in rat blood, liver and kidney. Int $\mathrm{J}$ Environ Res Public Health 2019; 16:274. doi: 10.3390/ijerph16020274

26. Rekha DK, Tripathi Y, Raghuveer CV, Pai SR, Ramaswamy C, Kamath P. Role of Vitamin $\mathrm{C}$ as an antioxidant in Cadmium chloride induced testicular damage. Int $\mathrm{J}$ Appl Biol Pharmaceut Tech 2011; 2(3): 484-488.

27. Sharaf AMM, Farrag AH, Fahmy HM. Protective effects of Vitamin $\mathrm{C}$ on Heamatological and Biochemical parameters of intoxicated male albino rats with Lead and Cadmium. Middle East J Appl Sci 2017; 7(1): 57-67.

28. Rani A, Kumar A, Lal A, Pant M. Cellular mechanisms of cadmium induced toxicity: A review. Int J Environ Health Res 


\section{ORunanu et al; Hepatarenal Histamarphalagy of Cadmium and Ascarlic Acid Treated Rats}

2014; $24: 378-399$.

29. Al Jamein N, Tabassum H, Fatima S, Ali MN, Rizwana H, Khan FA. Ameliorating effect of Vitamin $\mathrm{C}$ against potassium dichromate induced oxidative stress and inflammatory response in rats. Int $\mathrm{J}$ Pharmacol 2017; 13(8): 990-999. doi: 10.3923/ijp.2017.990.999

30. Adeneye AA and Olagunju JO. Protective effect of oral ascorbic acid (Vitamin C) against acetaminophen-induced hepatic injury in rats. Afr J Biomed Res 2008; 11: 183-190.

31. Dawud A, Eze ED, Ardja AA, Isa AS, Jimoh A, Bashiru M, Malgwi IS. Ameliorative effects of vitamin $\mathrm{C}$ and Zinc in alloxaninduced diabetes and oxidative stress in Wistar rats. Curr Res $\mathbf{J}$ Biol Sci 2012; 4(2): 123-129.

Copyright: (C) the author(s), 2020. It is an open-access article distributed under the terms of the Creative Commons Attribution License (CC BY 4.0), which permits authors to retain ownership of the copyright for their content, and allow anyone to download, reuse, reprint, modify, distribute and/or copy the content as long as the original authors and source are cited.

How to cite this article: Okwuonu UC, Omotoso DR, Bienonwu EO, Adagbonyin O, Dappa J. Histomorphological Profile of Liver and Kidney Tissues of Albino Wistar Rats Following Exposure to Cadmium-Induced Damage and Ascorbic Acid Supplementation. Acad. Anat. Int. 2020;6(1):30-34.

DOI: dx.doi.org/10.21276/aanat.2020.6.1.7

Source of Support: Nil, Conflict of Interest: None declared. 